\title{
Local Outcomes of Federal and State Urban \& Community Forestry Programs
}

\author{
Richard J. Hauer, Gary R. Johnson, and Michael A. Kilgore
}

\begin{abstract}
Increasing local urban and community forestry (U\&CF) programs and activities in the United States is a goal of state and federal U\&CF programs. This study found local U\&CF programs within the 50 United States increased in activity between 1997 and 2002 at a $2.1 \%$ annual rate of increase. Several attributes of state U\&CF forestry programs from a multiple regression model and correlation analysis partially explain the increase in local U\&CF program activity. The number of technical assists in a state were a strong predictor for increased local activity. Less certainty was found with state money used to fund the state U\&CF program or the use of cost-share assistance (Federal Cooperative Forestry Assistance Challenge Cost-share Grants) and this increase. Study findings provide evidence that state and federal U\&CF programs within the United States are furthering the building of capacity and development of local U\&CF programs.

Key Words. Building Capacity; Financial and Technical Assistance; Urban and Community Forestry.
\end{abstract}

Urban forestry exists at local, state, and federal levels within the United States. Each level has roles with the outcome of growing and maintaining an urban tree population. Local urban forestry programs are focused on planting, maintaining, and removing trees as needed (Elmendorf et al. 2003); Treiman and Gartner 2004; Kuhns et al. 2005). State urban and community forestry (U\&CF) programs were created to assist urban forestry efforts at local levels (Casey and Miller 1988), while federal U\&CF programs assist states and local entities to ultimately grow urban tree populations (Hauer et al. 2008).

An important need for enhancing urban forestry activities exists at the local level. The majority (58\%) of communities within the United States currently do little or nothing to manage their tree populations (Hortscience and Aslan Group 2004; Hauer 2005; Hauer and Johnson 2008). Several reasons (e.g., community members championing an urban forestry cause, funding, community size, technical ability and experience of staff, political support, program cost, and/or equipment) explain the ability or inability of local urban forestry programs to implement systematic efforts to manage urban tree populations (Kielbaso 1990; Tschantz and Sacamano 1994; Elmendorf et al. 2003; Schroeder et al. 2003; Treiman and Gartner 2004; Kuhns et al. 2005; Wall et al. 2006; Stevenson et al. 2008). Even though only $42 \%$ of communities are known to demonstrate urban forestry activity, this is an increase from 28\% in 1997 and 7\% in 1987 (Hanson et al. 1987, as cited in Davis 1993; Hauer 2005). Activity can range from rudimentary efforts such as tree planting only, to programs with sufficient inputs to sustain the urban forest at a desired level (Clark et al. 1997; Hauer 2006; Hauer and Johnson 2008).

In the United States, state and federal U\&CF programs were first created in the late 1960 s and early 1970 s to provide technical and financial assistance to local urban forestry programs
(Hauer et al. 2008). The Federal Farm Bill of 1990 (P.L. 101513) substantially increased U\&CF funding for the United States Department of Agriculture Forest Service (USFS). This resulted in state programs increasing technical and financial assistance to local urban forestry programs (Casey and Miller 1988; Hortscience and Aslan Group 2004; Hauer 2005; Hauer and Johnson 2008; Hauer et al. 2008). State and federal investments in local UF programs undertook to enhance local program capacity, foster development and enhancements of program structure and inputs, and move communities toward a sustainable urban forest (Clark et al. 1997; Dwyer et al. 2003; Hortscience and Aslan Group 2004; U.S. House of Representatives 2004; Konijnendijk et al. 2004; Hauer 2006). For example, The USFS, through the U\&CF program, has as a stated role to "increase the capacity of State forestry agencies, local governments, and the private sector to create and implement local programs that will sustain and improve urban and community natural resources."

State and federal U\&CF program cooperation occurs through federal technical and financial support of state U\&CF programs and regular federal assessments of state U\&CF program outcomes (Hortscience and Aslan Group 2004; Hauer et al. 2008). These assessments or program reviews are used, along with annual reporting, to retain, modify, and create future assistance mechanisms to support increasing local U\&CF activity. Financial and technical assistance are two common mechanisms used to ideally lead to increased local U\&CF program activities. This federal and state cooperative effort has expanded from pilot and rudimentary efforts in the late 1960s and early 1970s to all states now having a state U\&CF coordinator and often regional staff who deliver state U\&CF program activities (Hauer and Johnson 2008; Hauer et al. 2008). But have federal and state U\&CF programs led to a change in local U\&CF activity? 
This study asked whether attributes of state and federal U\&CF programs within the 50 United States are related or explain increased local urban forestry activity. First, the study authors examined whether urban forestry activity within local U\&CF programs had increased. Attributes of state U\&CF programs were then tested with an a priori multiple regression model that included indicators of technical assistance, financial assistance, and program money sources to determine if these were related to increased local urban forestry activity. These indicators were hypothesized to have an effect based on prior studies (Baugman 1980; Still et al. 1996; Vitosh and Thompson 2000; Bird 2002). Then, sequential and stepwise multiple regression techniques were used to explore if other indicators of state U\&CF programs further explained an increase in local urban forestry activity.

\section{METHODS}

\section{Data Sources}

Data used in this study was obtained from two sources. First, the USFS Performance Measures and Accountability System (PMAS) data for all 50 states (available by request from the USDA Forest Service, Northeastern Area State \& Private Forestry, Newtown Square, PA) was used to determine local U\&CF activity as the dependent variable (Appendix; Table 1). The study authors used the PMAS data as it was developed to measure urban forestry activity at the local level. The PMAS methods (USDA-FS 2003) guide state U\&CF coordinators to group communities into either an inactive ranking (no demonstrated urban forestry activity) or one of four activity rankings (project, formative, developmental, and sustained). Community activity increases from the lowest (project) to highest (sustained). Community activity rankings were developed by state U\&CF program leaders using USFS guidelines for each geographical political subdivision (community) with 100 or more people within a state. Second, a self-administered questionnaire completed by state $\mathrm{U} \& \mathrm{CF}$ program coordinators was used to develop the model data set of independent variables (Appendix). Portions of the 16-page questionnaire used for this study asked staffing levels, state and federal money for program operation and grants, technical assistance types and frequency, year program started, other agencies who provide state U\&CF assistance, program coordination, input with developing the state U\&CF strategic plan, and state council coordination. State $\mathrm{U} \& \mathrm{CF}$ coordinators are responsible for delivery of U\&CF assistance to local urban forestry programs and document local-level assistance provided and outcomes. Questionnaire delivery used the Tailored Design Method and 84\% of the 50 state U\&CF coordinators responded, with all questionnaires usable except for one returned but not completed (Hauer 2005; Dillman 2007; Hauer and Johnson 2008). Non-response error or non-item response error was not detected (Hauer 2005; Hauer and Johnson 2008).

\section{Study Questions}

Three study questions were created before data analysis: 1) Has local urban forestry activity increased nationally between 1997 and 2002, within each PMAS activity level and at the composite (sum of all four) activity levels? 2) Are U\&CF program indicators and attributes of financial assistance, technical assistance, and program money sources related to effective state programs, with effective being interpreted as an increase in the composite local-level urban forestry program activity within a state? 3) Are there other attributes or indicators of state $\mathrm{U} \& \mathrm{CF}$ programs related to a change in the composite local-level urban forestry activity within a state?

\section{Statistical Procedure}

Descriptive statistics, t-tests, correlation, and multiple regression modeling used SPSS version 18.0. A paired t-test was used to test for differences in local urban forestry activity between 1997 and 2002. Scaling of continuous variables was done by dividing the dependent and independent variables by the number of communities in each state. It is possible that nonscaled results may

Table 1. Model variables used in the a priori models and exploratory models.

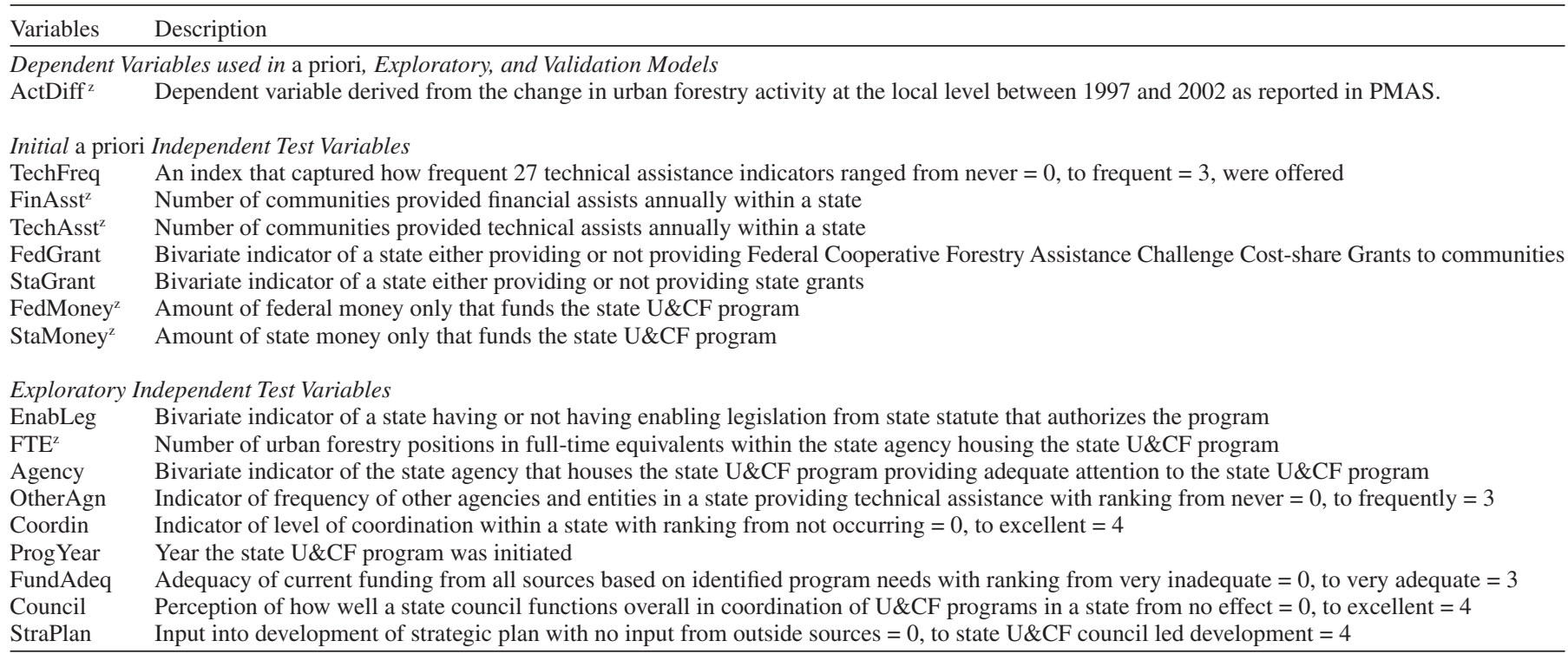

${ }^{\mathrm{z}}$ Scaled variable by dividing by number of communities in the state from which the data were derived. 
have artificially higher correlations, $\mathrm{R}^{2}$, and significance statistics. The scaled variables reduce the concern of artificially higher results. A multiple regression model was used as an a priori test of the relationship among independent variables (indicators) and the dependent variable (ActDiff). The dependent variable was derived from the composite change in the number of communities reported to have urban forestry activity in 2002 from 1997 within each of the 41 states used in this study. The composite value was derived from the number of communities in a state that were within one of the four activity rankings. The scaled dependent variable ActDiff $=($ Act2002/number communities in 2002) - (Act1997/number communities in 1997); whereas Act2002 = number of communities within a state reported to have urban forestry activity in 2002, and Act1997 = number of communities within a state reported to have urban forestry activity in 1997.

The seven independent variables TechFreq, TechAsst, FinAsst, FedGrant, StaGrant, FedMoney, and StaMoney (Table 1; Table 2) were initially hypothesized and tested to explain change on ActDiff and selected based on evidence that technical assistance, financial assistance, and program money resources lead to a change in activity (Baugman 1980; Still et al. 1996; Vitosh and Thompson 2000; Bird 2002). The model dates were selected since the PMAS data compilation started in 1997 and 2002 was the questionnaire study year. After testing and refinement of the initial a priori model, exploratory testing of additional independent variables (OtherAgn, EnabLeg, FTE, Agency, Coordin, ProgYear, FundAdeq, Council, and StraPlan) occurred through sequential and stepwise multiple regression techniques (Table 2). These variables where used as anecdotal effect is presumed or hypothesized for putative effect and addressed if staffing levels, agency support, funding adequacy, other agencies involved in state $\mathrm{U} \& \mathrm{CF}$, coordination with U\&CF delivery, state U\&CF council involvement, strategic planning, enabling legislation, and when the state U\&CF was created. The final model was cross-validated using the activity difference in communities between 1997 and 2003, 1997 and 2004 , interpreting validation through comparable sign and value of parameters. Ideally, validation occurs with a different population (e.g., country) or in a more distant time period; however, no data currently exists to do this, this approach is offered as the best available, and often validation modeling is not done in studies.

Significance for all tests, except where noted, used an $\alpha \leq 0.05$ significance level as evidence to reject a null hypothesis that no increase in urban forestry activity occurred. Indicator selection used an $\alpha \leq 0.25$ significance level for initial screening of variables and an $\alpha \leq 0.10$ significance level for retention in the final model. Outliers within the multiple regression model were discerned us- ing the Mahalanobis distance procedure at the $<0.001$ significance level and none was found (Mertler and Vannatta 2005). Assumptions of normality, linearity, and homoscedasticity were also met using bivariate plots between independent and dependent variables and a plot of the standardized residuals and standardized predicted values from the final multiple regression model. Examination for multicolliniarity in models used variance inflation factor statistics with a lack of multicolliniarity interpreted read as tics with a lack of multicolliniarity interpreted as the variance inflation factor <10 (Neter et al. 1990; Mertler and Vannatta 2005).

\section{RESULTS}

\section{Local Urban Forestry Activity}

Mean local urban forestry activity increased between 1997 and 2002 (Figure 1). The composite mean level increase averaged $2.1 \%$ annually (t-value $=3.979, \mathrm{n}=49, \mathrm{p}<0.000$ ). A likewise $2.1 \%$ annual decrease with the mean number of communities rated as inactive or nonparticipatory in local urban forestry programming was found $(\mathrm{t}$-value $=-2.491, \mathrm{n}=49, \mathrm{p}=$ $0.016)$. The PMAS categories of sustained (t-value $=2.244, \mathrm{n}$ $=48, \mathrm{p}=0.029)$, developmental $(t$-value $=3.181, \mathrm{n}=49, \mathrm{p}=$ $0.003)$, and project ( $\mathrm{t}$-value $=2.632, \mathrm{n}=49, \mathrm{p}=0.011)$ demonstrated significant increases in U\&CF activity (Figure 1). Communities rated within the formative category had no significant change $(\mathrm{t}$-value $=1.616, \mathrm{n}=48, \mathrm{p}=0.113)$. There was no significant change in the total number of communities $(\mathrm{t}$-value $=0.862, \mathrm{n}=49, \mathrm{p}=0.393)$ between 1997 and 2002.

\section{Initial a priori Model}

Initial exploratory modeling found staffing level scaled by community as significant and was included in the initial a priori model. From the full model of eight independent variables, four indicators provided evidence of the change in local program activity (Table 3). Pearson's correlation coefficients also suggest a relationship for three independent variables (TechAsst, TechFreq, and StaGrant) and change in activity over the study period (Table 3). The number of communities receiving technical assistance (TechAsst), frequency of technical assistance types to communities (TechFreq), the amount of state government money allocated to the state U\&CF program (StaMoney), and staffing level (FTE) were selected for further testing (Table 3). State money used with grants (StaGrant), Federal Cooperative Assistance Challenge Cost-share Grants (FedGrant), the

Table 2. Pearson's correlation coefficients of variables used in the initial a priori model.

\begin{tabular}{|c|c|c|c|c|c|c|c|c|}
\hline & ActDiff $^{2}$ & FinAsst $^{\mathrm{z}}$ & TechAsst $^{\mathrm{z}}$ & TechFreq & FedGrant & StaGrant & FedMoney $^{\mathrm{z}}$ & StaMoney \\
\hline ActDiff $^{2}$ & 1 & 0.023 & 0.478 (**) & $0.340(*)$ & -0.075 & $0.322(*)$ & -0.062 & 0.250 \\
\hline FinAsst $^{\mathrm{z}}$ & 0.023 & 1 & $\left.0.339{ }^{*}\right)$ & -0.011 & 0.198 & 0.246 & $0.355(*)$ & $0.377(* *)$ \\
\hline TechAsst $^{\mathrm{z}}$ & $0.478(* *)$ & $0.339(*)$ & 1 & 0.121 & -0.176 & 0.218 & $0.473(* *)$ & $0.494(* *)$ \\
\hline TechFreq & $0.340(*)$ & -0.011 & 0.121 & 1 & -0.035 & 0.099 & -0.252 & 0.125 \\
\hline FedGrant & -0.075 & 0.198 & -0.176 & -0.035 & 1 & $-0.301(*)$ & 0.222 & -0.076 \\
\hline StaGrant & $0.322(*)$ & 0.246 & 0.218 & 0.099 & $-0.301(*)$ & 1 & $-0.339(*)$ & 0.389 (**) \\
\hline FedMoney ${ }^{z}$ & -0.062 & $0.355(*)$ & $0.473(* *)$ & -0.252 & 0.222 & $-0.339(*)$ & 1 & $0.281(*)$ \\
\hline StaMoney $^{z}$ & 0.250 & 0.377 (**) & $0.494(* *)$ & 0.125 & -0.076 & 0.389 (**) & $0.281(*)$ & 1 \\
\hline FTE $^{z}$ & -0.014 & $0.401(* *)$ & $0.643(* *)$ & 0.014 & -0.008 & -0.085 & $0.686(* *)$ & $0.616(* *)$ \\
\hline
\end{tabular}

${ }^{\mathrm{z}}$ Scaled variable by dividing by number of communities in the state from which the data were derived.

* Correlation is significant at the 0.05 probability level (2-tailed).

** Correlation is significant at the 0.01 probability level (2-tailed). 


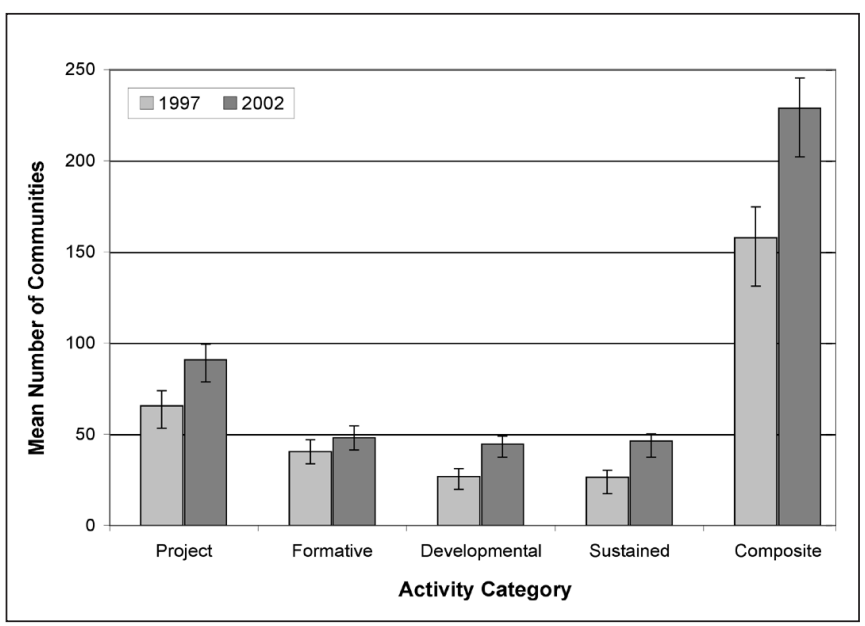

Figure 1. Mean change in communities with local urban and community forestry activity within the $\mathbf{5 0}$ United States between 1997 and 2002. (Bars are standard error of the mean, activity categories rank communities in a state from rudimentary activity in project to sustained activity with infrastructure sufficient to maintain status quo of the U\&CF program, composite is the sum of all four activity categories in a state, no significant change in the number of communities within a state between 1997 and 2002.)

amount of federal money provided to state U\&CF programs (FedMoney), and the number of communities receiving financial assistance (FinAsst) were not significant (t-value $<1$, and $\mathrm{p}>$ 0.25 , in all cases). The StaGrant indicator was correlated with ActDiff, but not significant in the regression model. The indicators in the final model had a positive effect on activity change except FTE which offered a negative effect on activity. States with more communities had fewer staff proportionally scaled to communities per state, which may be the reason for this finding. Staffing level was positively correlated and strongly correlated with FinAsst, TechAsst, FedMoney, and StaMoney.

\section{Exploratory Model}

Subsequent exploration of additional independent variables (OtherAgn, EnabLeg, Agency, Coordin, Prog Year, FundAdeq, Council, and StraPlan) on ActDiff in the refined final a priori model occurred (data not shown). None of these additional exploratory independent variables from Table 2 significantly added to the explanation of ActDiff when added individually to the final a priori model (t-value $<1.5$, and $\mathrm{p}>0.15$, in all cases). The exploratory variables ProgYear, EnabLeg, and StraPlan were possible indicators $(\mathrm{p}<0.25)$ when tested against ActDiff in an alternate model. However, these final exploratory models offered an inferior explanation of ActDiff (Adj $\mathrm{R}^{2}$ $=0.129, \mathrm{p}=0.044$ ) compared to the final a priori model (Adj $\left.\mathrm{R}^{2}=0.451, \mathrm{p}<0.000\right)$. In addition, stepwise multiple regression approaches (forward, backward, and stepwise selection) with all exploratory variables in the final a priori models did not add these three into the final $a$ priori models. Subsequently, no additional variables are supported for addition in the final a priori model with the exception of FTE, as noted earlier.

\section{Validation Models}

Similar outcomes were detected in the validation models as found with the final a priori model on ActDiff (data not shown). The models found a similar explanation of the variance with consistent parameter strength and sign. Overall, the validation models provide evidence supporting the final a priori models.

\section{DISCUSSION}

Results from this study have implications with developing policy and direction for state and federal U\&CF programs. During the study period, an increase in local urban forestry activity occurred. A major finding suggests technical assistance is a strong explanation of increased local urban forestry activity. Less certainty was found with state money allocated to the state U\&CF program

Table 3. Initial and final a priori models testing the relationship between indicators of technical assistance, financial assistance, grants, staffing level, and state U\&CF program money sources on change in local U\&CF activity within a state.

\begin{tabular}{|c|c|c|c|c|c|c|c|}
\hline \multirow[t]{2}{*}{$\begin{array}{l}\text { Model } \\
\text { variables }^{z}\end{array}$} & \multicolumn{2}{|c|}{$\begin{array}{l}\text { Unstandardized } \\
\text { coefficients }\end{array}$} & \multirow{2}{*}{$\begin{array}{c}\text { Standardized } \\
\text { coefficients } \\
\text { Beta }\end{array}$} & \multicolumn{2}{|c|}{ t-test Statistics } & \multicolumn{2}{|c|}{ Correlations } \\
\hline & $\mathrm{B}$ & Std. Error & & t-value & Sig. ${ }^{y}$ & Zero-order & Partial \\
\hline \multicolumn{8}{|c|}{ Initial Model All Indicators $\left(\mathrm{R}^{2}=0.523 \mathrm{R}_{\text {adj }}^{2}=0.403\right.$, std. error of est. $\left.=0.159, \mathrm{~F}(8,32)=4.378, \mathrm{p}<0.001\right)$} \\
\hline (Intercept) & -0.360 & 0.193 & & -1.868 & 0.071 & & \\
\hline FinAsst & -0.233 & 0.281 & -0.127 & -0.829 & 0.413 & 0.023 & -0.145 \\
\hline TechAsst & 0.638 & 0.153 & 0.765 & 4.162 & 0.000 & 0.478 & 0.593 \\
\hline TechFreq & 0.145 & 0.085 & 0.231 & 1.695 & 0.100 & 0.340 & 0.287 \\
\hline FedGrant & 0.062 & 0.077 & 0.116 & 0.815 & 0.421 & -0.075 & 0.143 \\
\hline StaGrant & 0.023 & 0.077 & 0.056 & 0.299 & 0.767 & 0.322 & 0.053 \\
\hline FedMoney & 7.209E-6 & 0.000 & 0.038 & 0.177 & 0.860 & -0.062 & 0.031 \\
\hline StaMoney & $8.025 \mathrm{E}-5$ & 0.000 & 0.262 & 1.379 & 0.177 & 0.250 & 0.237 \\
\hline FTE & -9.291 & 3.480 & -0.640 & -2.670 & 0.012 & -0.014 & -0.427 \\
\hline \multicolumn{8}{|c|}{ Final a priori Model $\left(\mathrm{R}^{2}=0.506, \mathrm{R}_{\text {adj }}^{2}=0.451\right.$, std. error of est. $\left.=0.152, \mathrm{~F}(4,36)=9.215, \mathrm{p}<0.000\right)$} \\
\hline (Intercept) & -0.298 & 0.156 & & -1.915 & 0.063 & & \\
\hline TechAsst & 0.620 & 0.130 & 0.743 & 4.757 & 0.000 & 0.478 & 0.621 \\
\hline TechFreq & 0.142 & 0.075 & 0.227 & 1.904 & 0.065 & 0.340 & 0.302 \\
\hline FTE & -9.480 & 2.504 & -0.653 & -3.785 & 0.001 & -0.014 & -0.534 \\
\hline
\end{tabular}

${ }^{\mathrm{z}}$ Dependent Variable: ACTDIFF = scaled change in the number of communities demonstrating rudimentary to advanced urban and community forestry activity between 1997 and 2002 within a state.

y Independent variables regarded as significant with t-value probability $<0.25$ in the initial model, and $<0.10$ in the final model. 
and increased local U\&CF activity. Staffing levels scaled to the number of communities in a state were negatively related to increased activity in the regression model. An interpretation of this may be that states with more communities have proportionally fewer staff, which affects the delivery of technical assistance. Technical assistance was a positive indicator of increased activity and likewise had a strong positive correlation with staffing level. There were other attributes of the state U\&CF program, such as coordination with the state urban forestry council and grants, which were not significant in the final a priori models. That does not mean these or other attributes measured, or not quantified in this study are unimportant, but may in fact be accounted for in other significant variables. For example, staff is needed to carry out technical and financial assistance. There was a strong positive correlation between FTE (scaled to community) and the number of technical assists, federal money, and state money. Federal and state money sources also had a significant positive relationship with the number of technical and financial assists to local urban forestry programs. Alternatively, a decrease in staff and funding could correspond to a reduction in local urban forestry activity. State U\&CF councils help set state U\&CF program policy, which is reflected in how state U\&CF programs conduct their assistance programs (Hauer 2007; Hauer and Johnson 2008). Key study outcomes and their relationship related to local urban forestry development follow.

\section{Technical and Financial Assistance Effects}

Financial assistance and technical assistance are two specific means used to build local U\&CF capacity measured through greater local activity in U\&CF programs (Dwyer et al. 2003; Elmendorf et al. 2003; Hauer and Johnson 2008; Hauer et al. 2008). This is the first study to quantify the effects of technical and financial assistance together on building local U\&CF activity at the national level. Others studies have looked at financial assistance programs within an individual state, but empirical findings of the effects of technical assistance on change in local U\&CF activity are not known to exist (Still et al. 1996; Vitosh and Thompson 2000; Bird 2002). There was no attempt to quantify and determine if different types of assistance forms (e.g., management plan development, inventory systems, tree planting, ordinance development) are better or worse than one another. Other studies have found financial assistance leads to increased tree management plans, Arbor Day celebrations, Tree City USA designations, tree ordinances, urban forest management plans, tree plantings, and tree inventories which seem primarily oriented with public lands (Still et al. 1996; Vitosh and Thompson 2000; Bird 2002; Hauer 2005).

The study authors found technical assistance played an important role with increased local U\&CF activity. Standardized beta coefficients are one way to provide a consistent mechanism for similarly comparing the net effect of model attributes. The standardized beta coefficients suggest the number of community contacts through technical assistance has a 2.9 times greater effect on local U\&CF change than state government money allocated to the U\&CF program. Technical assistance contacts are an important way to build local U\&CF activity and programs and for every technical assistance contact, a 0.743 change in activity occurred. Thus, more than $70 \%$ of the time assistance results in increased activity. State U\&CF coordinators also believe that technical assistance is slightly more effective at increasing lo- cal U\&CF capacity than financial assistance which is consistent with the a priori model results (Hauer 2005; Hauer 2007).

Less certainty with financial assistance was found in this study for explaining increased local U\&CF activity. Financial assistance, often through grants, provides money to fund activities such as tree inventories, storm response planning, management plans, tree risk assessment, and others (Still et al. 1996; Vitosh and Thompson 2000; Bird 2002; Hauer et al. 2008). Federal Challenge Grants or state money allocated through grants did not significantly explain a change in local U\&CF activity in the regression model. This might reflect that only $39 \%$ of states used state money for grants, compared to $83 \%$ of states using federal money for grants (Hauer and Johnson 2008). Also, it is possible the time-period of this study did not allow outcomes of grants to fully materialize. The study authors also found a strong correlation with state government funding and its eventual distribution through grants $(0.389, \mathrm{p}=0.012)$ and states that use state grants on activity $(0.322, \mathrm{p}=0.040)$, suggesting importance of state money used for grants to ideally build local U\&CF activity.

These results compare with other studies from rural forests that found both technical and financial assistance mechanisms led to improved private forest management (Gaddis et al. 1995; Haines 1995; Cubbage et al. 1996; Kilgore and Blinn 2003). Studies of nonindustrial private forest owners of rural forests conclude technical assistance, financial assistance, and education led to positive outcomes in many but not all cases (e.g., increased number of planted trees, increased timber stand improvement, increased stumpage value, and greater residual remaining timber).

When developing technical and financial assistance programs, understanding the perceptions and beliefs of seekers of, providers for, assistance is useful. Recipients often believe financial assistance is the most important way to increase local U\&CF capacity (Wray and Prestemon 1983; Bird 2002; Hortscience and Aslan Group 2004; Straka et al. 2005). However, state foresters and state U\&CF coordinators believe that technical assistance is more important when the state agency plays the provider role to local recipients. Thus, both financial and technical assistance are perceived important; however, contrary to recipient perceptions or desires, this study found technical assistance had a greater impact with increased local activity.

\section{Importance of Money Allocations for U\&CF Program Outcomes}

Money is important to fund the state U\&CF program. Money sources for state U\&CF programs come from many sources with federal and state money combined accounting for over $90 \%$ of monies that fund state U\&CF programs (Hauer and Johnson 2008). The amount of program money allocated by state government to the state U\&CF program was important and positively related to technical assistance, financial assistance, and staffing levels. Approximately $40 \%$ of states do not directly fund their state U\&CF program, which instead relies on federal or other funding sources (Hauer and Johnson 2008).

No relationship was found for federal money allocated to state U\&CF programs and local activity change within the multiple regression models. This does not mean that federal money allocations are unimportant. Hauer (2005) did find a moderate correlation $(0.394, p=0.011)$ between change in local activity and federal money allocated to states. The effect of federal money on increased local U\&CF activity could be reflected through federal money al- 
located to states that was strongly correlated with money subsequently accounted for and transferred to local U\&CF programs through technical assists $(0.473, \mathrm{p}=0.002)$ which was one of four predictors in the final a priori model. Finally, federal money accounts for $60 \%$ of state U\&CF program funding and it is used to support staff which conduct technical assistance which was a significant attribute with building local urban forestry (Hauer and Johnson 2008). This study found moderate to strong correlations between federal and state funding sources and the number of technical and financial assists in a state. Thus, even though the federal money attribute was not directly significant in explaining a change in the multiple regression model, it was presumably captured in other ways with the overall increase in local U\&CF activity.

A strong correlation exits between perception of the strength of state U\&CF program continuation $(0.666, p=0.000)$ and statelevel government funding (Hauer 2005). Interestingly, no relationship existed between this perception and the level of federal funding $(0.168, p=0.293)$. A significant correlation (data not shown) was found in this study with the amount of state government funding of state U\&CF programs and the year the state program was initiated $(-0.352, \mathrm{p}=0.024)$, number of full-time equivalent state $\mathrm{U} \& \mathrm{CF}$ employees $(0.468, \mathrm{p}=0.002)$, perception of adequacy with state government funding of the program $(0.307, p$ $=0.017$ ), and percentage of full-time employment the state U\&CF coordinator would be at today if the federal U\&CF program was not expanded in $1991(0.460, \mathrm{p}=0.002)$. Correlation evidence suggests that elimination of federal funding would have less effect on the state U\&CF programs $(-0.607, \mathrm{p}=0.000)$ that have taken an active role to use state funds above the base provided by the USFS. Thus, state U\&CF programs that have been around longer and have a greater input of state government financing, have a tendency to have greater capacity to be self sufficient and led to greater local U\&CF activity during the study time period.

\section{CONCLUSION}

In summary, this study found strong evidence that technical assistance from state U\&CF programs translates into increased local U\&CF activity. It was determined there is less certainty with state money allocations to the state U\&CF program or the use of grants and their relationship with increased local activity. The ten-year period of this study may impact discovery of a relationship between some indicators and the increased activity detected over the study period. This offers a model to study the outcome of state and federal U\&CF programs on local urban forestry activity in the future and over a longer period of time. Regardless, a link to increased local activity through activities from state U\&CF programs was found.

\section{LITERATURE CITED}

Baughman, M.J. 1980. The role of government in urban forestry. In: Proceedings of the 1979 Convention of the Society of American Foresters. Society of American Foresters. Washington, D.C. pp. 302-306.

Bird, J. 2002. Pass-through Grants from Federal Sources to State Agencies as an Effective Tool to Develop Sustainable Community Forestry Programs at the Local Level. Unpublished manuscript. North Dakota State Forest Service, Bismarck, ND. 42 pp.

Casey, C.J., and R.W. Miller. 1988. State government involvement in community forestry: A survey. Journal of Arboriculture 14:141-144.
Clark, J.R., N.P. Matheny, G. Cross, and V. Wake. 1997. A model of urban forest sustainability. Journal of Arboriculture 23:17-30.

Cubbage, F.W., B.D. New, and R.J. Moulton. 1996. Evaluations of technical assistance programs for nonindustrial private forest land owners. In: M.J. Baughman (Ed.), Proceedings for Symposium on Nonindustrial Private Forests: Learning from the Past, Prospects for the Future. St. Paul, MN: University of Minnesota, Extension Special Programs. pp. 367-376.

Davis, R.L. 1993. Street tree trends in Kansas and the influence of community factors. Journal of Arboriculture 19:201-208.

Dillman, D.A. 2007. Mail and Internet Surveys: The Tailored Design Method Second Edition 2007 Update with New Internet, Visual, and Mixed-Mode Guide. John Wiley and Sons, New York, NY. 523 pp.

Dwyer, J.F., D.J. Nowak, and M.H. Noble. 2003. Sustaining urban forests. Journal of Arboriculture 29:49-55

Elmendorf, W.F., V.J. Cotrone, and J.T. Mullen. 2003. Trends in urban forestry practices, programs, and sustainability: Contrasting a Pennsylvania, U.S., study. Journal of Arboriculture 29:237-248.

Gaddis, D.A., B.D. New, F.W. Cubbage, R.C. Abt, and R.J. Moulton. 1995. Accomplishments and economic evaluations of the forestry incentives program: A review. Southeastern Center for Forest Economics Research Working Paper No. 78.53 pp.

Haines, T. 1995. Federal and state forestry cost-share assistance programs: Structure, accomplishments, and future outlook. United States Department of Agriculture-Forest Service, Southern Forest Experiment Station, New Orleans, LA. Research Paper SO-295, 18 pp. Accessed December 31, 2010. <http://www.srs.fs.usda.gov/pubs/804>

Hauer, R.J. 2005. Urban Forest and Urban Forestry Capacity: Defining Capacity and Models of Capacity Building. Doctoral Dissertation. Department of Forest Resources, University of Minnesota. Accessed December 31, 2010. <http://www.uwsp.edu/cnr/forestry/faculty/hauer/Files/Hauer\%20Dissertation.pdf>

Hauer, R.J. 2006. Urban forestry capacity building and models. In: V.D. Phillips and R. Tschida (Eds.). Proceedings of the 4th International Conference on Environmental Management for Sustainable Universities, June 26-30, 2006. Global Environmental Management Education Center, College of Natural Resources, University of WisconsinStevens Point, WI. pp. 1-24.

Hauer, R.J. 2007. State and federal development of local urban forestry activities. Proceedings of the 2007 Convention of the Society of American Foresters. Sustaining America's Forests, Portland, OR. October 23-27, 2007. Society of American Foresters. Bethesda, MD. pp. $1-12$.

Hauer, R.J., and G.R. Johnson. 2008. State urban and community forestry program funding, technical assistance, and financial assistance within the 50 United States. Arboriculture \& Urban Forestry 34:280-289.

Hauer, R.J., C.J. Casey, R.W. Miller. 2008. Advancement in state government involvement in urban and community forestry in the 50 United States: Changes in program status from 1986 to 2002. Arboriculture \& Urban Forestry 34:5-12.

Hortscience and Aslan Group. 2004. Assessment of the USDA Forest Service Urban \& Community Forestry Program. Prepared for the National Urban \& Community Forestry Advisory Council, USDA Forest Service. Hortscience, Pleasanton, CA. 47 pp. Accessed December 31, 2010. <http://www.treelink.org/linx/?navSubCatRef=58>

Kielbaso, J.J. 1990. Trends and issues in city forests. Journal of Arboriculture 16:69-76.

Kilgore, M.A., and C.R. Blinn. 2003. Policy tools to encourage the application of sustainable timber harvesting practices in the United States and Canada. Forest Policy and Economics 6:111-127. 
Konijnendijk, C.C., S. Sadio, T.B Randrup, and J. Schipperijn. 2004. Urban and peri-urban forestry in a development context - strategy and implementation. Journal of Arboriculture 30:269-276.

Kuhns, M., B. Lee, and D. Reiter. 2005. Characteristics of urban forestry programs in Utah, U.S. Journal of Arboriculture 31:285-295.

Mertler, C.A., and R.A. Vannatta. 2005. Advanced Multivariate Statistical Methods. Third Edition. Pyrczak Publishing. Los Angeles, CA. 347 pp.

Neter, J., W. Wasserman, and M.H. Kutner. 1990. Applied Linear Statistical Models: Regression, Analysis of Variance, and Experimental Design. Third Edition. Richard Irwin, Inc. Homewood, IL. 1181 pp.

Schroeder, H.W., T.L. Green, and T.J. Howe. 2003. Community tree programs in Illinois, U.S.: A statewide survey and assessment. Journal of Arboriculture 29:218-225.

Stevenson, T.R., H.G. Gerhold, and W.F. Elmendorf. 2008. Attitudes of municipal officials toward street tree programs in Pennsylvania, U.S. Arboriculture \& Urban Forestry 34:144-151.

Still, D., B. Fair, and H. Gerhold. 1996. Community forestry grants in Pennsylvania: How effective are they. Journal of Forestry 94(1):26-30.

Straka, T.J., A.P. Marsinko, and C.J. Childers. 2005. Individual characteristics affecting participation in urban and community forestry programs in South Carolina, U.S. Journal of Arboriculture 31:131-137.

Treiman, T., and J. Gartner. 2004. Community forestry in Missouri, U.S.: Attitudes and knowledge of local officials. Journal of Arboriculture 30:205-213

Tschantz, B.A., and P.L. Sacamano. 1994. Municipal tree management in the United States. Davey Research Group and Communication Research Associates, Inc. Report, Kent, OH. 58 pp.

U.S. House of Representatives. 2004. A report to the committee on appropriations U.S. House of Representatives on the U.S. Forest Service Urban and Community Forestry Program. Surveys and Investigations Staff, March 2004. Accessed December 31, 2010. <http:// www.treelink.org/linx/?navSubCatRef=58>

USDA-FS. 2003. Performance measurement accountability system desk guide revised June. United States Department of Agriculture, Forest Service, State and Private Forestry. Accessed December 31, 2010. <http:// www.fs.fed.us/spf/coop/library/PMAS\%20DeskGuide\%202004.pdf>

Vitosh, M.A., and J.R. Thompson. 2000. Iowa communities benefit from an externally funded tree-planting program. Journal of Arboriculture 26:114-119

Wall, B.W., T.J. Straka, and S.M. Miller. 2006. An econometric study of the factors influencing participation in urban and community forestry programs in the United States. Arboriculture \& Urban Forestry $32: 221-228$

Wray, P.H., and D.R. Prestemon. 1983. Assessment of street trees in Iowa's communities. Iowa State Journal of Research 58:261-268.

Acknowledgments. We thank the University of Minnesota Graduate School for a Thesis Research Grant, the Department of Forest Resources, and the University of Wisconsin - Stevens Point for partial financial support with this study. We also thank the advice and suggestions of anonymous reviewers and Paul Doruska with improvement of this paper and the statistical approach presented in this paper.

Richard J. Hauer (corresponding author)

Associate Professor of Urban Forestry

College of Natural Resources

University of Wisconsin-Stevens Point

Stevens Point, WI 54481, U.S.

rhauer@uwsp.edu
Gary R. Johnson

Professor of Urban and Community Forestry

College of Food, Agricultural and Natural Resource Sciences

Department of Forest Resources

University of Minnesota

1530 Cleveland Avenue North

St. Paul, MN 55108, U.S

Michael A. Kilgore

Professor of Natural Resource Economics and Policy

College of Food, Agricultural and Natural Resource Sciences

Department of Forest Resources

University of Minnesota

1530 Cleveland Avenue North

St. Paul, MN 55108, U.S

Résumé. Accroître les programmes et les activités liés aux projets de foresterie urbaine et communautaire (en anglais: U\&CF) aux États-Unis est le but premier des programmes fédéraux et d'état en foresterie urbaine. Cette étude a permis de constater que ces programmes au sein des 50 états des États-Unis ont permis d'accroître l'activité dans ce domaine entre 1997 et 2002 à un taux annuel de 2,1\%. Plusieurs facteurs des programmes de foresterie urbaine au sein des états ont permis d'expliquer partiellement cet accroissement d'activité, et ce au moyen d'un modèle d'analyse de régression multiple et de corrélation. Le nombre d'assistants techniques constituait un facteur de prédiction fort d'un accroissement de l'activité locale. Moins de certitude était observée en relation avec les fonds publics de l'état consacrés pour les programmes d'état en foresterie urbaine ou leur investissement dans des programmes de subvention à partage de coûts. L'étude a permis d'établir une preuve quant à l'effet positif des programmes d'état et fédéraux en foresterie urbaine pour construire une capacité et un développement accru au sein des programmes locaux en foresterie urbaine.

Zusammenfassung. Wachsende lokale urbane und kommunale Forstprogramme und Aktivitäten in den Vereinigten Staaten sind ein Ziel der staatlichen und behördlichen Forstprogramme. Diese Studie fand heraus, daß locale Forstprogramme innerhalb von 50 Bundesstaaten der USA zwischen 1997 und 2002 mit einer jährlichen Rate von 2,1\% wachsen. Verschiedene Attribute von staatlichen Forstprogrammen aus einem multiplen Regressionsmodell und Korrelationsanalyse erklären teilweise den Zuwachs der lokalen Forstprogramm-Aktivitäten. Weniger Sicherheit wurde festgestellt bei den staatlichen Zuwendungen zu diesen Programmen oder der Hinzuziehung von Kostenteilungsassiststenz (Federal Cooperative Forestry Assistance Challenge Cost-share Grants) und deren Zuwachs. Die Ergebnisse dieser Studie liefern den Nachweis, daß Staatliche und behördliche Forstprogramme innerhalb der Vereinigten Staaten die Schaffung von Kapazität und Entwicklung lokaler Forstpgrogramme voranbringen.

Resumen. El incremento de los programas locales y comunitarios de dasonomía urbana y sus actividades en los Estados Unidos es un objetivo de los programas estatales y federales U\&CF. Este estudio encontró que los programas locales U\&CF dentro de los 50 estados incrementaron en actividad entre 1997 y 2002 a la tasa anual del $2.1 \%$. Varios atributos de los programas, de un modelo de regresión múltiple y análisis de correlación, explicaron parcialmente el incremento en la actividad de los programas locales U\&CF. La asistencia técnica en un estado fue un fuerte predictor del incremento de la actividad local. Se encontró menos certeza con el dinero usado en el programa o el uso del costo de asistencia (Federal Cooperative Forestry Assistance Challenge Cost-share Grants) y este incremento. Los resultados del estudio dan evidencia de que los programas U\&CF estatales y federales dentro de los Estados Unidos están adicionando la capacidad de construcción y desarrollo de los programas U\&CF locales. 


\section{APPENDIX. DEFINITIONS OF PERFORMANCE MEASURES ACCOUNTABILITY SYSTEM (PMAS) LEVELS USED TO INSTRUCT STATE U\&CF PROGRAM PERSONNEL TO RANK COMMUNITIES IN THEIR STATE.}

\section{PMAS Level \\ Project (lowest rank)}

Formative

Developmental
Description (PMAS Desk Guide Ver. 10/2003)

Project level communities are those where assistance to do projects, such as Arbor Day, tree planting, grants, or one-time events are taking place. These communities have not expanded from projects to program with infrastructure for conserving, establishing, or managing trees, forests, green space, and related natural resources within their environments.

Formative level communities have recognized that trees, forests, and green space are assets to their community and are initiating community-based natural resource programs with the help of urban and community forestry program technical or financial assistance. Technical assistance activities under this stage include the establishment of citizen organizations and structures with interest in trees, forests, and related natural resources in their community, discussions with community leaders, basic or more comprehensive assessments of natural resources and/or conditions, Arbor Day celebrations, organized community meetings, networking, and coordination.

Developmental communities have initiated community-based forestry and natural resource related programs and are pursuing additional activities to improve and enhance these resources. Technical assistance activities include assisting citizen organizations and advisory or governing organizations in planning, policy and budget development, meetings, workshops, urban natural resource inventories and ecological assessments, management plan and/or ordinance development, review of policies related to land use and development, and engaging in partnership development.

Sustained (greatest rank) Sustained level communities have a community-based forestry or natural resource program organized well enough that community-based organizations or municipal agencies are functioning on their own with appropriate support from multiple levels. Annual planning, community leadership, and a systematic approach to conservation and management of trees, forests, and related natural resources characterize these communities. Technical assistance enhances existing programs but is more infrequent than in previous levels. 